JRPIPM. Vol. 3 (2020, no. 2, 92-101)

Jurnal Riset Pendidikan dan Inovasi Pembelajaran Matematika

ISSN: 2581-0480 (electronic)

URL: journal.unesa.ac.id/index.php/jrpipm

\title{
Profil Argumentasi Siswa dalam Memecahkan Masalah PISA-like Berdasarkan Model Toulmin
}

\author{
Putri Pramesti ${ }^{1}$, Abdul Haris Rosyidi ${ }^{2}$ \\ ${ }^{1}$ Universitas Negeri Surabaya, pramesti2406@gmail.com \\ ${ }^{2}$ Universitas Negeri Surabaya, abdulharis@unesa.ac.id
}

\begin{abstract}
ABSTRAK
Argumentasi merupakan bagian penting dalam memahami matematika karena siswa mengemukakan suatu klaim didasari oleh data dan dukungan teori yang memadai dari suatu masalah. Salah satu satu jenis soal yang melatih kemampuan argumentasi siswa adalah soal model PISA. Tujuan penelitian ini adalah mendeskripsikan profil argumentasi siswa dalam memecahkan masalah PISA. Penelitian ini adalah penelitian deskriptif kualitatif yang menggunakan teknik sampling dengan variasi maksimal sehingga diperoleh tiga subjek penelitian yang memiliki jawaban atau klaim berbeda. Data diperoleh melalui tes dan wawancara dan dianalisis menggunakan argumentasi Toulmin. Hasil penelitian menunjukkan bahwa dua siswa dengan klaim benar, memiliki data yang lengkap sebagai dasar memutuskan klaim dan menghubungkannya dengan berbagai waran antara lain himpunan atau tabel, lalu mencocokkan data yang ada. Siswa-siswa ini memberi backing terhadap waran menggunakan konsep penjumlahan dan pengurangan bilangan. Sedangkan siswa dengan klaim salah, tidak memiliki data yang cukup akibat salah dalam memahami informasi yang diberikan. Siswa menggunakan waran berupa konsep penjumlahan dan pengurangan bilangan. Namun, waran tersebut tidak memiliki backing yang mendukung.
\end{abstract}

Kata Kunci: argumentasi matematis, model Toulmin, masalah PISA

\begin{abstract}
Argumentation is an important part in understanding mathematics because students make a claim based on data and adequate theoretical support of a problem. One type of problem that can measure students' argumentation skills is the PISA model problem. This is a qualitative descriptive study aiming at describing the profile of students' arguments in solving PISA problems. As many as three participants with different answers and claims were selected using sampling techniques with maximum. Data were obtained through tests and interviews and analyzed using Toulmin's model of argumentation. The results showed that two students with true claims, had complete data as the basis for deciding claims and linking them with various warrants including sets or tables, then matching existing data. These two participants gave backing to warrants using the concepts of addition and subtraction of numbers. Meanwhile, the student participants with false claims, ddid not have enough data due to incorrect understanding of the information provided. They used
\end{abstract}

Tanggal Masuk: 7 Oktober 2019; Revisi: 27 April 2020; Diterima: 30 April 2020 
warrants in the form of the concept of addition and subtraction of numbers. However, the warrants do not have any supporting backing.

Keywords: mathematical argumentation, Toulmin's model of argumentation, PISA probelm

\section{Pendahuluan}

Penalaran merupakan aspek penting dalam belajar matematika. Sebagaimana tercermin pada kompentensi inti dalam Kurikulum 2013 yaitu mengolah, menalar, dan menyaji dalam ranah konkret dan ranah abstrak terkait dengan pengembangan dari yang dipelajarinya di sekolah secara mandiri, bertindak secara efektif dan kreatif, serta mampu menggunakan metoda sesuai kaidah keilmuan [1]. Brodie [2] mengemukakan bahwa ketika siswa bernalar dalam memecahkan suatu masalah, siswa mengembangkan argumen-argumen untuk meyakinkan diri sendiri maupun orang lain. Mengembangkan dan mengevaluasi argumen dan bukti matematika merupakan salah satu bagian dalam memahami matematika [3].

Argumentasi menurut Vincent [4] diartikan sebagai suatu pernyataan yang didukung oleh bukti-bukti sehingga dapat mempengaruhi pikiran orang lain. Seperti yang dijelaskan Toulmin, argumentasi melibatkan kombinasi dari klaim, data, waran, bantahan, kualifikasi, dan backing [5]. Klaim yaitu pernyataan yang validitasnya sedang dibuat, data merupakan fondasi argumen didasarkan atas fakta-fakta yang relevan dengan klaim. Pernyataan yang menghubungkan data dengan klaim disebut waran, pernyataan yang menggambarkan waran tidak berlaku disebut bantahan, sedangkan kualifikasi yaitu pernyataan yang menggambarkan kepastian klaim. Seseorang membuat semacam klaim (bisa merupakan jawaban atas suatu masalah) agar pernyataannya dianggap sebagai bagian dari argumen. Kemudian hubungan antara data dan klaim harus diklarifikasi melalui waran tentang bagaimana klaim itu dibuat berdasarkan data yang diperoleh. Waran dapat berbentuk rumus, definisi, aksioma, atau teorema maupun membuat analogi, gambar, atau diagram dan grafik. Selain itu, dapat terjadi klarifikasi tambahan yang disebut dengan backing tentang mengapa waran berlaku.

Argumentasi matematis seseorang dapat diukur melalui soal yang mendukung siswa untuk memberikan klaim, data, dan waran. Penulis berargumen hal ini dapat ditemui pada soal jenis kontekstual, seperti yang ada pada jenis soal PISA matematika. Sesuai dengan kerangka PISA, kemampuan yang diukur dalam soal PISA adalah kemampuan untuk melakukan proses merumuskan, menerapkan, dan menafsirkan matematika ke dalam berbagai konteks, dimana kemampuan dasar matematika seperti penalaran dan argumentasi diperlukan dalam ketiga proses tersebut [6-7]. Hal ini sejalan dengan pendapat Wardhani dan Rumiati [8] bahwa soal model PISA lebih mengukur kemampuan bernalar, pemecahan masalah, serta beragumentasi dibandingkan kemampuan yang berkaitan dengan ingatan dan hitungan. Oleh karena tipikal soal model PISA adalah soal kontekstual dimana konteks menjadi penting untuk dilibatkan dalam proses penyelesaian, maka seorang pemecah masalah PISA perlu melibatkan pengetahuan kontekstualnya.dalam penyajian klaim, data, dan waran.

Penelitian terkait eksplorasi argumentasi seseorang di bidang matematika sudah banyak dilakukan [5,9-10]. Namun, penelitian sebelumnya belum secara eksplisit mengkaji tentang argumentasi siswa dalam memecahkan masalah PISA. Penelitian yang sudah ada, misalkan Sáenz [11] mengungkapkan bagaimana individu melibatkan kompetensi matematika, yang salah satunya adalah penalaran dan argumentasi, dalam menyelesaikan masalah PISA. Penelitian tentang bagimana kaitannya kajian argumentasi matematika dengan model Toulmin (klaim, data, waran) belum dilaporkan pada soal 
kontekstual jenis PISA. Sementara itu, model Toulmin sendiri telah banyak digunakan oleh peneliti-peneliti sebelumnya dalam mengkaji proses argumentasi siswa dalam matematika [12-13]. Dengan alasan ini, penelitian ini mendeskripsikan profil argumentasi siswa dalam memecahkan masalah PISA.

\section{Metode Penelitian}

Penelitian ini merupakan penelitian deskriptif kualitatif, dengan tujuan untuk memperoleh gambaran tentang argumentasi matematis siswa dalam memecahkan masalah. Subjek dari penelitian ini merupakan siswa kelas VIII di sebuah SMP negeri di Magetan. Pemilihan subjek menggunakan sampling dengan variasi maksimal yaitu mencari sampel kasus atau individu yang memiliki perbedaan dalam hal karakteristik atau sifat-sifat yang dimiliki [14]. Perbedaan yang dimaksud dalam penelitian ini didasarkan pada keragaman dan kebenearan cara yang digunakan siswa.

Penelitian dilakukan dengan memberikan tes tertulis berupa masalah mirip PISA atau PISA-like, yaitu masalah yang dikembangkan sesuai dengan kerangka PISA [15]. Sesuai dengan profil pada kerangka PISA, soal yang dikembangkan ini memiliki kategori proses 'menafsirkan' (interpret) karena dominansi proses literasi matematikaterletak pada proses menafsirkan hasil matematika kembali ke dalam konteks dunia nyata. Dalam soal ini, siswa dituntut untuk membuat model matematika sederhana terkait dengan informasi tekstual yang berhubungan dengan kuantitas (bilangan) untuk kemudian menggunakan model matematika itu untuk membuat interpretasi dari proses pemecahan masalah yang dihasilkan. Soal ini berkategori konteks personal karena berhubungan dengan kehidupan pribadi siswa.

\section{Grup Video Call}

Dimas (dari Surabaya, Indonesia) dan Chan (dari Tokyo, Jepang) berencana untuk merayakan ulang tahun Vernon yang berasal dari London, Inggris, melalui group video call. Untuk menentukan waktu yang tepat untuk video call, Dimas melihat waktu di masing-masing negara, seperti terlihat pada gambar di bawah ini.
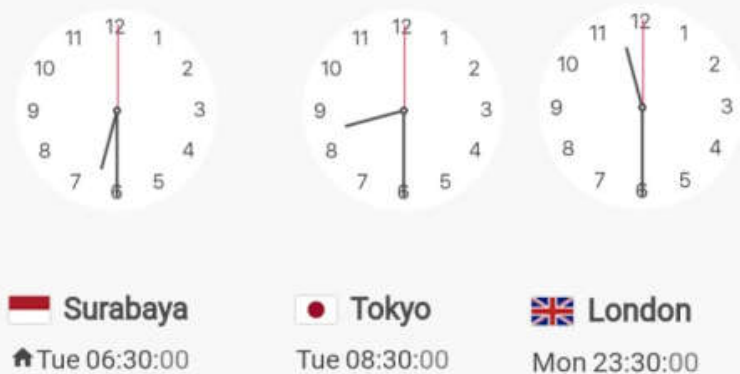

Tue 08:30:00 Mon 23:30:00

(timeanddate.com)

Dimas, Chan, dan Vernon tidak bisa melakukan group video call saat sekolah. Dimas sekolah dari pukul 7.00 AM - 3.00 PM WIB, Chan sekolah dari pukul 8.30 AM-3.30 PM JST, sedangkan Vernon sekolah dari pukul 8.40 AM -3.30 PM waktu London. Jam tidur mereka pukul 10.00 PM-5.00 AM waktu setempat. Dengan kondisi tersebut, maka kapan waktu terbaik untuk Dimas, Chan, dan Vernon melakukan group video call jika ulang tahun Vernon hari Selasa, 9 Januari 2019? (Waktu untuk group video call yaitu seperempat jam) 
Setelah memperoleh data tes tertulis dan wawancara, dilakukan analisis dengan mengadaptasi model argumentasi Toulmin seperti yang ditunjukkan oleh gambar 1 (Conner et al, 2014) yaitu sebagai berikut.

a. Mengidentifikasi klaim dengan mencatat pernyataan dalam tes tertulis maupun hasil wawancara subjek.

b. Mencari kemungkinan data yang mendukung setiap klaim .

c. Mencari waran yang menunjukkan hubungan bagaimana data mendukung klaim tertentu. Jika tidak ada waran yang dapat diidentifikasi, klaim tersebut bukan bagian dari penelitian karena tidak dianggap sebagai argumen.

d. Mencari kemungkinan backing untuk waran tersebut

e. Menafsirkan kemungkinan elemen dari suatu argumen dan menulis argumen yang direkonstruksi seperti gambar berikut.

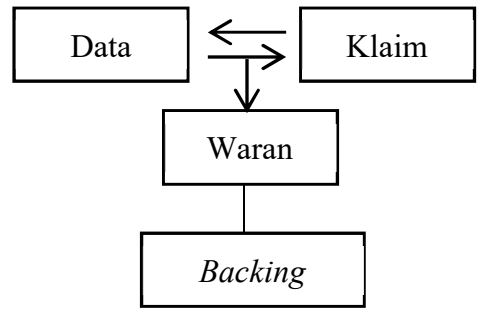

Gambar 1. Model Argumentasi Toulmin

Setelah dilakukan tes tulis terhadap 27 siswa, diperoleh 2 siswa dengan jawaban benar, 10 siswa dengan jawaban salah, dan 15 siswa yang tidak menjawab. Dua siswa (QQ dan DM) dengan jawaban benar memiliki cara berbeda dalam menyelesaikan masalah. Subjek QQ menggunakan relasi dan himpunan sedangkan subjek DM menggunakan konsep relasi dan aljabar. Karena cara yang digunakan kedua siswa tersebut berbeda, maka keduanya diambil sebagai subjek penelitian. Selain itu, dari 10 siswa dengan jawaban salah, tidak diperoleh keragaman jawaban sehingga hanya diambil satu subjek penelitian (RN). Dengan demikian, di penelitian ini diperoleh tiga subjek penelitian yaitu QQ, DM, dan RN.

\section{Hasil dan Pembahasan}

\subsection{Argumentasi Matematis Subjek QQ}

Klaim (dalam hal ini jawaban untuk masalah) yang dibuat oleh subjek QQ yaitu waktu luang Dimas, Chani, dan Vernon untuk melakukan videocall. Klaim tersebut ditunjukkan oleh gambar 2 berikut.

$$
\text { Yadi, mereka bisa video eall diantara pukul } 3.01 \text { PM }-5.39
$$

Gambar 2. Klaim Subjek QQ

Berdasarkan hasil tes tertulis subjek QQ, diperoleh data yang mendukung klaim tersebut yaitu waktu sekolah dan tidur Dimas, Chani, dan Vernon dalam WIB. Gambar 3 berikut merupakan data yang digunakan QQ. 


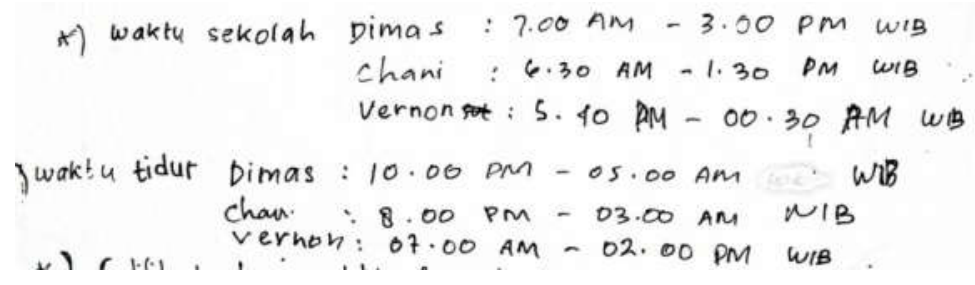

Gambar 3. Data Subjek QQ

Data tersebut diperoleh QQ setelah mengubah yang diketahui, waktu sekolah dan tidur Chan serta Vernon, ke dalam zona waktu yang sama yaitu WIB.

Waran yang digunakan QQ sebagai 'jembatan' penghubung antara data dan klaim berupa konsep gabungan, komplemen, dan selisih himpunan. Gambar 4 menunjukkan hasil tertulis subjek QQ yang menunjukkan waran tersebut.

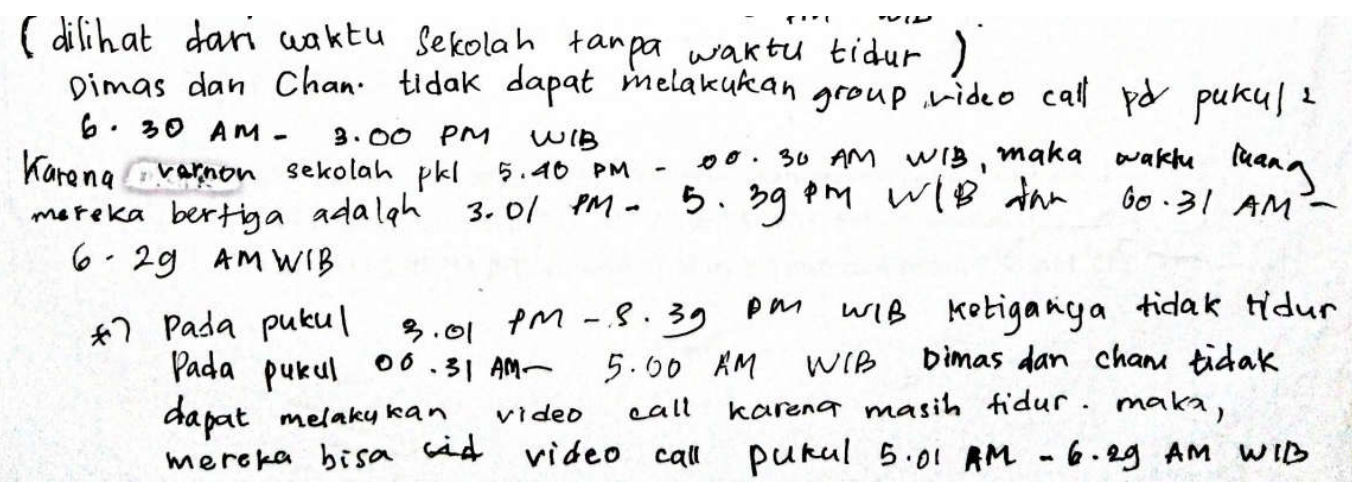

Gambar 4. Waran Subjek QQ

Untuk memperjelas hasil tertulis subjek QQ, maka dilakukan wawancara berikut.

P Coba kamu jelaskan secara singkat langkah-langkahmu untuk menentukan nilai yang belum diketahui!

Q Seperti himpunan gitu mbak, pertama saya menggabungkan waktu sekolah

Q Dimas dan Chan. Dari gabungan tersebut, saya cari komplemennya. Setelah ketemu komplemennya, baru saya kurangi dengan waktu sekolah Vernon. Lalu diperoleh rentang waktu yaitu pukul 3.01 PM sampai 5.39 PM dan 00.31 AM sampai 6.29 AM WIB. Kedua rentang waktu tersebut, saya kurangi dengan waktu tidur Dimas, Chan, maupun Vernon sehingga diperoleh pukul 3.01 PM - 5.39 PM WIB. Jadi bisa saya simpulkan mereka dapat melakukan videocall diantara jam tersebut tanpa mengganggu waktu tidur maupun sekolah ketiganya.

Berdasarkan hasil tertulis dan wawancara, mula-mula subjek QQ menentukan gabungan dari himpunan waktu sekolah Dimas dan Chan. Dari proses tersebut, didapatkan rentang waktu mereka tidak dapat melakukan videocall dikarenakan sekolah. Selanjutnya QQ menentukan komplemen dari hasil gabungan dua himpunan tersebut. Lalu subjek QQ menentukan selisih dari hasil komplemen dengan waktu sekolah Vernon akibatnya diperoleh dua rentang waktu mereka dapat melakukan videocall tanpa memperhatikan waktu tidur. Setelah memperoleh dua rentang waktu tersebut, subjek QQ menentukan selisihnya dengan waktu tidur ketiganya sehingga diperoleh klaim yaitu 
waktu terbaik yang digunakan ketiganya untuk videocall tanpa mengganggu waktu sekolah dan tidur.

Kemudian backing yang mendukung waran tersebut yaitu waktu tidur dan sekolah Chan dan Vernon yang diubah ke dalam satu zona waktu, dalam hal ini WIB dengan menggunakan konsep pengurangan dan penjumlahan bilangan.

Berdasarkan model Toulmin, berikut rangkuman argumen subjek QQ.

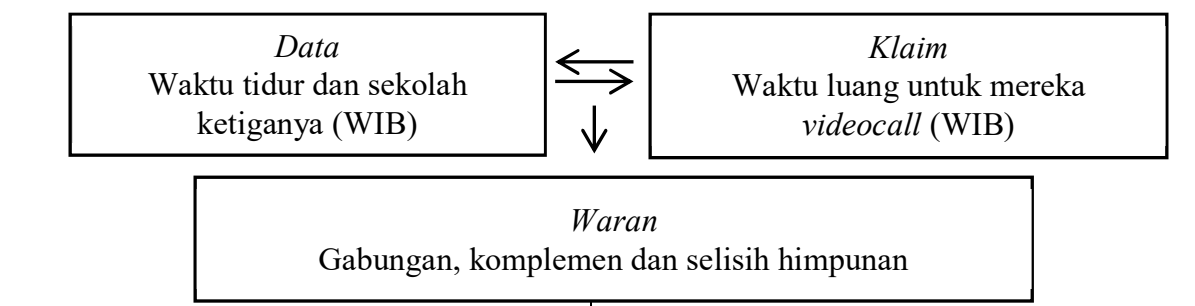

Backing
Waktu tidur dan sekolah Chan dan Vernon (JST dan waktu London) diubah ke WIB

Gambar 5. Rangkuman Argumen Subjek QQ

\subsection{Argumentasi Matematis Subjek DM}

Berikut ini hasil analisis argumentasi matematis subjek DM. Klaim subjek DM (dalam hal ini jawaban untuk masalah yang diberikan) yaitu waktu dimana Dimas, Chan, dan Vernon untuk melakukan videocall tanpa mengganggu waktu tidur dan sekolah ketiganya. Klaim tersebut ditunjukkan oleh gambar 6 berikut.

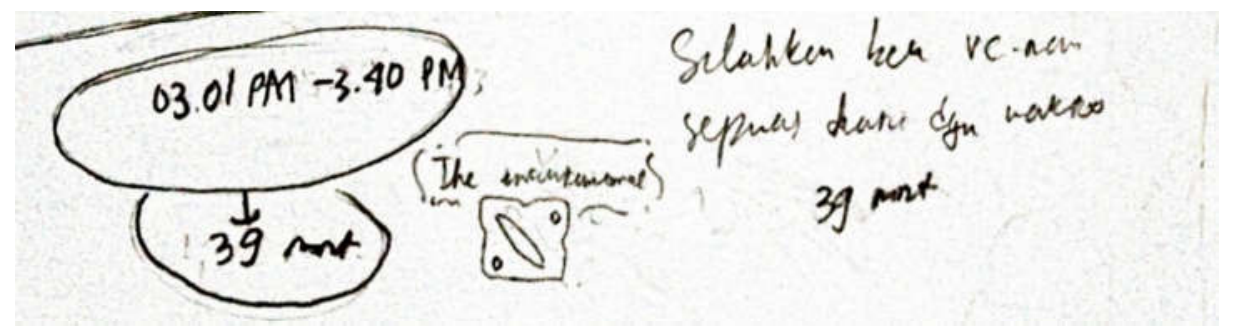

Gambar 6. Klaim Subjek DM

Klaim DM didukung oleh data yaitu waktu sekolah dan tidur ketiganya dalam WIB yang ditunjukkan berturut-turut oleh $a$ dan $b$ pada gambar berikut.

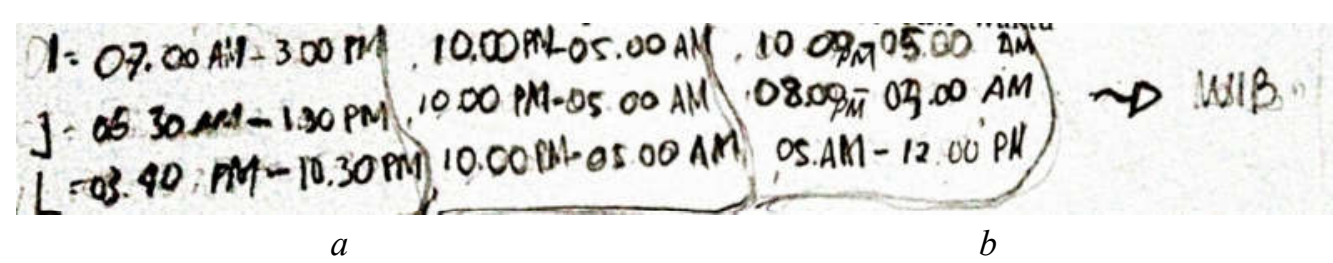

Gambar 7. Data Subjek DM

Berdasarkan gambar 7 tersebut, waran yang digunakan subjek DM berupa tabel untuk membantu menentukan waktu kosong diantara waktu sekolah dan tidur Dimas (I), Chan (J), dan Vernon (L). Subjek DM menentukan waktu kosong Dimas (I) yang berarti waktu dimana Dimas tidak sekolah dan tidur. Lalu DM mencocokkan apakah di rentang waktu tersebut Chan dan Vernon sekolah, tidur, 
atau tidak. Cara ini tidak terlihat dalam hasil tes tertulis DM namun dapat ditunjukkan oleh pernyataan DM dalam wawancara berikut.

P Jadi, coba jelaskan secara singkat langkah-langkahmu menentukan yang belum diketahui!

D Saya misalkan I merupakan waktu di Surabaya (Indonesia), J

M merupakan waktu di Tokyo (Jepang), dan L waktu di London (Inggris). Berdasarkan gambar jam dalam soal, diperoleh perbedaan waktu di antara tiga negara. Setelah itu, saya mengubah waktu sekolah dan tidur Chan dan Vernon ke dalam WIB menggunakan penjumlahan dan pengurangan. Baru saya menentukan jam kosong diantara ketiganya dengan cara menentukan waktu kosong Dimas terlebih dahulu baru saya cocokkan apakah di jam tersebut Chan dan Vernon sekolah, tidur atau tidak.

Backing yang mendukung waran subjek DM yaitu waktu sekolah dan tidur Chan dan Vernon yang diubah ke dalam zona waktu yang sama yaitu WIB. Subjek DM mengubah waktu tersebut dengan menggunakan konsep pengurangan dan penjumlahan bilangan. Berikut hasil tes tertulis DM yang menunjukkan backing yang digunakan.

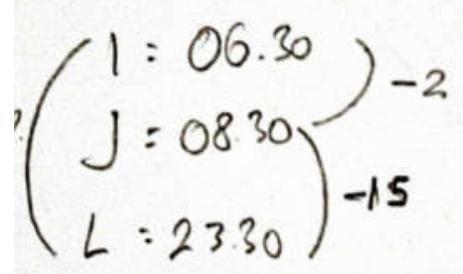

Gambar 8. Backing Data Subjek DM

Berdasarkan hasil tes tertulis tersebut, DM memisalkan I sebagai waktu di daerah Dimas dalam WIB, J sebagai waktu di daerah Chan dalam JST, dan L sebagai waktu di daerah Vernon dalam waktu London. Simbol -2 menunjukkan selisih antara I dan J yaitu 2 jam, sedangkan simbol -15 merupakan selisih antara J dan L yaitu 15 jam. Namun, DM melakukan kesalahan perhitungan pada saat menentukan perbedaan waktu antara $\mathrm{J}$ dan L. Hal itu dikarenakan DM tidak memperhatikan perbedaan hari di antara kedua negara.

Berikut rangkuman argumen subjek DM berdasarkan model Toumin.

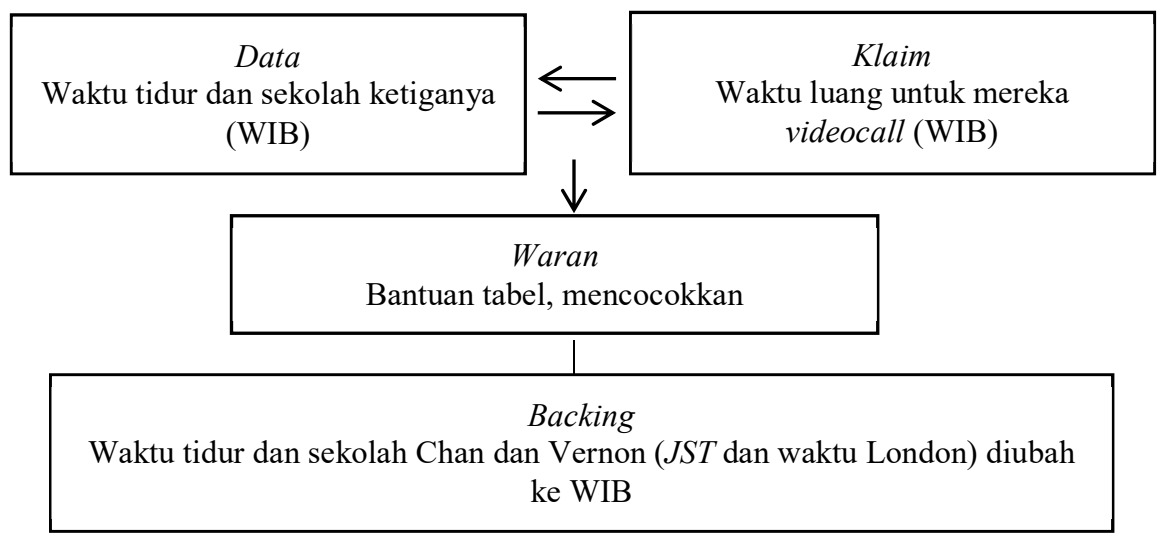




\subsection{Argumentasi Matematis Subjek RN}

Gambar 9. Rangkuman Argumen Subjek DM

Berikut ini hasil analisis argumentasi matematis subjek RN. Klaim (dalam hal ini jawaban untuk masalah) RN ditunjukkan oleh gambar 10 berikut.

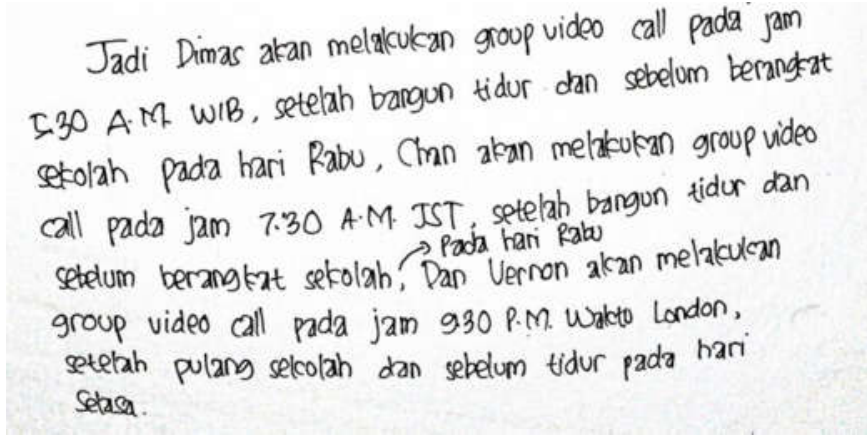

Gambar 10. Klaim Subjek RN

Data yang mendukung klaim subjek RN yaitu waktu sekolah dan tidur Dimas dalam WIB, Chan dalam JST, Vernon dalam waktu London. Namun, subjek RN salah mengartikan waktu setempat pada waktu tidur ketiganya. Karena hal tersebut, subjek RN menyimpulkan bahwa waktu tidur dalam soal yang diberikan sudah dalam bentuk WIB. Berikut kutipan wawancara yang menunjukkan kesalahan RN dalam memahami informasi yang diberikan.

P Apa saja informasi yang kamu peroleh dari masalah yang diberikan?

RN Diketahui Dimas sekolah pukul 7 pagi sampai 3 siang WIB, Chan sekolah pukul setengah 9 pagi sampai setengah 4 sore JST, dan Vernon sekolah pukul 8.40 pagi sampai setengah 4 sore waktu London. Dimas, Chan, dan Vernon tidur pukul 11 malam sampai 5 pagi waktu setempat. Lalu diketahui juga tanggal ulang tahun Vernon yaitu 9 Januari 2019.

P Bisa dijelaskan maksud waktu setempat?

RN Jadi waktu setempat itu waktu di tempat Dimas berada yaitu WIB karena di soal diketahui yang mengecek waktu di tiga negara tersebut adalah si Dimas yang berada di Surabaya, Indonesia.

Waran yang digunakan $\mathrm{RN}$ berupa konsep pengurangan bilangan untuk menentukan perbedaan waktu di antara ketiga negara dan penjumlahan bilangan untuk mengubah JST dan waktu London ke WIB. Lalu RN mengambil suatu waktu secara random dan mencocokkannya dengan waktu sekolah dan tidur mereka. Hal tersebut tidak terlihat dalam hasil tes tertulis RN namun terlihat pada kutipan wawancara berikut.

$\mathrm{P} \quad$ Kalau begitu coba jelaskan secara singkat langkah-langkahmu menentukan yang belum diketahui!

$\mathrm{RN}$ Pertama, saya menentukan perbedaan waktu antara ketiga negara yang diketahui yaitu Indonesia (Surabaya), Jepang (Tokyo), dan Inggris (London). Saya menentukannya dengan menggunakan operasi pengurangan bilangan. Setelah itu, diperoleh perbedaan waktu antara Surabaya dan Tokyo adalah 2 jam, sedangkan perbedaan waktu Tokyo dan London adalah 15 jam. Kemudian 
saya menentukan waktu yang tidak mengganggu jam sekolah dan tidur Dimas, Chan, maupun Vernon. Saya coba ambil pukul 5.30 WIB, lalu saya mengubahnya ke dalam JST dan waktu London. Karena perbedaan waktu WIB dan JST adalah 2 jam maka pukul 5.30 WIB samadengan pukul 7.30 JST. Sedangkan perbedaan waktu WIB dan waktu London adalah 15 jam, sehingga diperoleh pukul 5.30 AM WIB samadengan pukul 9.30 PM waktu London. Kemudian saya cocokkan dengan waktu sekolah dan tidur mereka, ternyata tidak mengganggu ketiganya.

Namun dalam hal ini, tidak ada backing yang mendukung waran yang digunakan RN. Berdasarkan hal tersebut, berikut rangkuman argumen RN menurut model Toulmin.

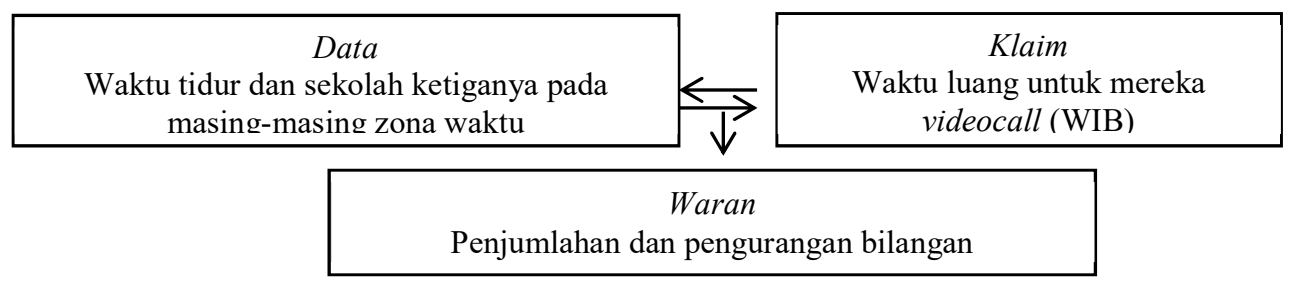

Gambar 11. Rangkuman Argumen Subjek DM

Hasil penelitian ini menunjukan bahwa siswa dengan klaim yang benar menunjukkan adanya waran yang lengkap dan mendukung klaim tersebut. Temuan ini menunjukkan bahwa strategi pemecahan masalah yang cukup kuat ditagih dalam masalah PISA yang diujikan menjadi poin penting dalam mempengaruhi kualitas backing yang bagus dalam mendukung waran yang diajukan siswa. Penyelesaian yang melibatkan pengetahuan kontekstual seperti yang ditunjukkan ketiga subjek dalam konteks personal, menunjukkan bahwa melalui argumentasi, siswa dapat membangun dan memperbaiki pemahaman mereka tentang ide-ide matematika dan membangun bersama pemahaman bersama [16]. Lebih lanjut, ini sejalan dengan pendapat Yackel [17] menunjukkan bahwa melalui argumentasi, siswa memiliki kesempatan untuk membuat koneksi antara topik matematika, dimana dalam hal ini subjek dalam penelitian ini melibatkan koneksi antar topic bilangan dan konteks dunia nyata.

\section{$4 \quad$ Penutup}

Berdasarkan hasil dan pembahasan, berikut profil argumentasi matematis siswa dalam memecahkan masalah PISA. Siswa dengan jawaban akhir atau klaim benar, memiliki data yang cukup lengkap sebagai dasar memutuskan klaim. Siswa menghubungkan data dengan klaim yang diambil dengan menggunakan berbagai waran, yaitu berupa konsep gabungan, komplemen, dan selisih himpunan atau menggunakan waran berupa tabel, lalu mencocokkan data pada tabel tersebut. Setelah menentukan waran, siswa memberi klarifikasi tambahan atau disebut dengan backing tentang alasan waran berlaku. Siswa mengidentifikasi backing tersebut dengan menggunakan konsep penjumlahan dan pengurangan bilangan.

Sedangkan siswa dengan jawaban akhir atau klaim salah, memiliki data yang kurang lengkap sebagai dasar memutuskan klaim. Hal tersebut disebabkan siswa melakukan kesalahan dalam memahami informasi yang diberikan. Siswa menghubungkan data yang diketahui dengan klaim yang dibuat dengan menggunakan konsep penjumlahan dan 
pengurangan bilangan. Konsep tersebut merupakan waran atau jembatan antara data dan klaim. Namun, waran yang digunakan oleh siswa tidak memiliki backing untuk mendukung waran tersebut.

\section{Daftar Pustaka}

[1] Kemendikbud, Peraturan Menteri Pendidikan dan Kebudayaan No 65 Tahun 2013 tentang Standar Proses. Jakarta: Kementerian Pendidikan dan Kebudayaan, 2013.

[2] K. Brodie, Teaching Mathematical Reasoning in Secondary School Classrooms. New York: Spinger, 2010.

[3] NCTM.. Principles and Standards for School Mathematic. Reston, VA: National Council of Teachers of Mathematics, 2000.

[4] R. R. Vincent, "Becoming a Critical Thinker. Boston: Houghton Mifflin Company.

[5] Conner et all. 2014. Teacher Support for Collective Argumentation: A Framework for Examining How Teachers Support Students' Engagement in Mathematical Activities", Educ Stud Math, vol 86: 401-429, 2009.

[6] K. Stacey, "The international assessment of mathematical literacy: PISA 2012 framework and items", In Selected regular lectures from the 12th International Congress on Mathematical Education (pp. 771-790). Springer, Cham, 2015.

[7] A. Pettersen, dan J. Braeken, "Mathematical competency demands of assessment items: A search for empirical evidence". International Journal of Science and Mathematics Education, vol. 17, no. 2, 405-425, 2019.

[8] S. Wardhani dan Rumiati, Instrumen Penilaian Hasil Belajar Matematika SMP: Belajar dari PISA dan TIMSS. Yogyakarta: PPPPTK, 2011.

[9] M. Mueller,"The co-construction of Arguments by Middle School Students", The Journal of Mathematical Behavior, vol. 28, 138-149, 2009.

[10] A. Nordin dan L. B. Boistrup, "A Framework for Identifying Mathematical Arguments as Supported Claims Created in Day-to-Day Classroom Interactions", The Journal of Mathematical Behavior, vol. 51, 15-27.

[11] C. Sáenz, "The role of contextual, conceptual and procedural knowledge in activating mathematical competencies (PISA)", Educational Studies in Mathematics, vol. 71, no. 2, 123-143, 2009.

[12] N. Metaxas, D. Potari, dan T. Zachariades, "Analysis of a teacher's pedagogical arguments using Toulmin's model and argumentation schemes", Educational Studies in Mathematics, vol. 93, no. 3, 383-397, 2016.

[13] S. Erduran, "Toulmin's argument pattern as a "horizon of possibilities" in the study of argumentation in science education", Cultural Studies of Science Education, vol. 13, no. 4, 1091-1099, 2018.

[14] J. W. Creswell, Research Design, Pendekatan Kualitatof, Kuantitatif, dan Mixed Edisi Ketiga. Bandung: Pustaka Belajar, 2008.

[15] Organisation for Economic Co-operation and Development, PISA 2012 assessment and analytical framework: Mathematics, reading, science, problem solving and financial literacy, OECD Publishing, 2013.

[16] M. Staples, J. Newton, K. Kosko, A. Conner, M. Cirillo, dan K. Bieda, "Conceptions and consequences of what we call argumentation, justification, and proof", In Proceedings of the 38th conference of the North-American chapter of the international group for the psychology of mathematics education, 1704-1712, Tuscon: PME-NA, 2016.

[17] E. Yackel, "What we can learn from analyzing the teacher's role in collective argumentation", The Journal of Mathematical Behavior, vol. 21, no. 4, 423-440, 2002. 